\title{
Costs and Returns of Mungbean in the Nagaur District of Rajasthan
}

\author{
Mahendra $^{1}$, Arjun Singh Rajput ${ }^{2}$, Anju Yadav ${ }^{2}$ and R.C. Kumawat ${ }^{3}$ \\ ${ }^{1}$ Department of Agricultural Economics, SKNAU, Jobner, Jaipur, Rajasthan, India \\ ${ }^{2}$ Department of Agricultural Economics and Management, Rajasthan College of Agriculture, MPUAT Udaipur, Rajasthan, India \\ ${ }^{3}$ Department of Agricultural Economics, SKNAU, Jobner, Jaipur, Rajasthan, India
}

"Corresponding author: arjnrjpt@gmail.com (ORCID ID: 0000-0002-1345-7718)

Received: $14-04-2020$

Revised: $17-07-2020$

Accepted: $23-08-2020$

\begin{abstract}
The present investigation was undertaken with a view to work out the costs of and returns from mungbean in the Nagaur district of Rajasthan. A random sample of 100 mungbean cultivators was selected for the study. Both primary and secondary data were used for the study. The primary data were collected from the selected mungbean cultivators, using personal interview method on pre-structured data schedule for the year 2015-16. On the selected farmers an average total cost of cultivation (cost $\mathrm{C}_{3}$ ) per hectare of mungbean was ₹ 31776.07 on large farms and ₹ 32092.8 on marginal farms. Overall gross income, family labour income, farm business income, net profit and cost of production were estimated at $₹ 50901$, ₹ 26370 , ₹ 36526, ₹ 21889 per hectare and ₹ 4534 per quintal. Return per rupee from mungbean cultivation was ₹ 1.77 per rupee invested on large farms and ₹ 1.45 per rupee invested on small sized farms with overall per rupee returns of ₹ 1.60 .
\end{abstract}

\section{Highlights}

(0 An average total cost of cultivation per hectare of mungbean was lower on large farms while return per rupee was higher on large farms than small farms.

Keywords: Cost of production, gross income, mungbean, Return per rupee, cost concept

India is the largest producer $(25 \%)$, consumer $(27 \%)$ and importer $(14 \%)$ of pulses in the world (Mohanty and Satyasai 2015). Pulses are one of the cheapest sources of protein for human consumption in India. The World Health Organization recommends the consumption of 80 grams per capita of pulses every day for India. There has been a multi-decadal mismanagement of pulse production in India with rice and wheat taking a bigger share of land. India therefore, needs a pulses revolution. Mungbean comes third after chickpea and pigeanpea among pulses crops. It occupies 40.70 lakh hectares and contributes 19.01 lakh tonnes in pulse production in the country during 2017-18 (Anonymous, 201718). In Rajasthan, total area under mungbean was 17.19 lakh hectares with the production of 12.22 lakh tonnes and productivity of $515 \mathrm{~kg} / \mathrm{ha}$ during 2017-18 (Anonymous, 2017-18). In Nagaur, total area under mungbean was 2.56 lakh hectares with the production of 1.80 lakh tonnes and productivity of $509 \mathrm{~kg} / \mathrm{ha}$ during the year 2017-18 (Anonymous, 2017-18).

Mungbean [Vigna radiata L.) R. Wilczek is known with different common names viz., mungbean, green gram and celera bean. Mungbean is a major edible legume crop in India. The grains contain approximately $25-28 \%$ protein, $1.0-1.5 \%$ oil, $3.5-4.5 \%$ fiber, $4.5-5.5 \%$ ash and $62-65 \%$ carbohydrates

How to cite this article: Mahendra, Rajput, A.S., Yadav, A. and Kumawat, R.C. (2020). Costs and Returns of Mungbean in the Nagaur District of Rajasthan. Economic Affairs, 65(3): 349-355.

Source of Support: None; Conflict of Interest: None 
on dry weight basis. Productivity of pulses can be increased through adoption of improved technology. Seeds, manures, plant protection measures, fertilizers, irrigation, human labour and tractor power are most important crucial inputs for increasing agricultural production in India. Costs in agriculture play a significant role in making the farm sector economically viable and feasible under the pressure of continuous rise in input prices affecting the profitability of the crop enterprises. Mungbean cultivation is labour-intensive pulse crop and it requires high dosages of manures and fertilizers (Rao and Tripathi 1979; Khunt and Desai 1996). The main constituent of the cost of cultivation of Mungbean is manures and fertilizers, followed by cost on family labour, hired labour and machine labour. Thus, the farmers should have to be motivated to diversify to more remunerative cropping patterns instead of the traditional, less profitable ones (Singh 1995). Similar types of results were reported by (Sharma et al. 2000; Maurya et al. 2001). This mechanism needs to be critically examined for formulating policies in relation to costs and output prices for understanding the income path in the farm sector. As such there is a need to study the costs of and returns from mungbean crop (Chatterjee et al. (2014).

\section{MATERIALS AND METHODS}

Among pulses, mungbean crop occupies first place in term of area and production in the rajasthan. Nagaur district occupies first place in terms of area and production of mungbean therefore, it was selected purposively for the study. A list of all the tehsils growing mungbean were obtained from district Headquarter. From this list two tehsils; namely Nagaur and Jayal were selected randomly.

Separate lists of all the villages growing mungbean were obtained from the selected tehsil Headquarters; from these lists six villages namely Goa Khurd, Bhakrod and Sinod (from Nagaur tehsil) Igyar, Bodwa and Nradhana (from Jayal tehsil) were selected randomly for the study. Thus, a sample of 100 farmers out of 1004 farmers from all five size group from the six villages was selected on random basis.

Separate lists of all the mungbean growing cultivators of the selected villages were prepared based on the information provided by the patwari, agriculture supervisor and other revenue officials. Then a representative sample of producer/farmer was selected taking 10 per cent farmers from each village. These farmers were categorized into five groups viz., marginal (0.51-2.00 ha), small (2.01-3.00 ha), semi-medium (3.01-5.00 ha), medium (5.01$7.00 \mathrm{ha})$ and large farmers (7.01-11.00 ha) based on the cumulative square root frequency method of stratification. Both primary and secondary data were used for analysis. The primary data were collected from the selected mungbean cultivators, using by personal interview method on prestructured data schedule for the year 2015-16. The secondary data were collected from various Publications and Records of Agriculture Statistics Cell, Nagaur district, Directorates of Economics and Statistics, Directorate of Agriculture, Krishi Pant Bhawan, Govt. of Rajasthan, Jaipur and its websites (www.rajsthankrishi.gov.in) for 41 years (1974-75 to 2014-15).

\section{ANALYSIS OF DATA}

After collection, the data were compiled, tabulation and analyzed according to the selection categories of sample farm and using varies statistical tools were used.

\section{Costs and returns structure}

The costs of and returns from mungbean was analyzed separately for the farmers to examine the economics of crop production. The cost concepts used for estimating costs, gross returns and net returns in respect of mungbean crop are given below:

\section{Cost concepts}

Costs were computed by following certain cost concepts and items of costs (all measured in monetary terms) as discussed below:

\section{Cost $A_{1}$ :}

(i) Value of hired human labour

(ii) Value of hired bullock labour

(iii) Value of owned bullock labour

(iv) Value of owned machinery

(v) Hired machinery charges

(vi) Value of seed (both farm produced and purchased) 
(vii) Value of manures (both farm produced and purchased)

(viii) Value of fertilizers

(ix) Value of insecticides and pesticides

(x) Irrigation charges

(xi) Depreciation on farm buildings and implements

(xii) Interest on working capital

(xiii) Insurance premium

(xiv) Land revenue

(xv) Miscellaneous expenses

Cost $A_{2}:$ Cost $A_{1}+$ rent paid for leased-in land

Cost $B_{1}$ : Cost $A_{1}+$ interest on fixed capital (excluding land)

Cost $B_{2}$ : Cost $B_{1}+$ rental value of owned land + rent paid for leased-in land

Cost $C_{1}$ : Cost $B_{1}+$ imputed value of family labour

Cost $C_{2}$ : Cost $B_{2}+$ imputed value of family labour

Cost $C_{3}$ : Cost $C_{2}+10$ per cent of $\operatorname{cost} C_{2}$ as management cost

\section{Interest on fixed capital}

Interest on present value of fixed assets (excluding land) such as implements, machinery and buildings were calculated at the rate of 12 per cent per annum as per the rate charged by the banks.

\section{Interest on working capital}

Working capital or variable cost included the expanses on cash cost items like seeds, manure, fertilizers, chemicals, labour (family labour plus hired labour), repair and maintenance of machinery and machines hired for operations. The actual prices paid out by the farmers for these items were taken in to account. The interest on variable cost, excluding owned resources like family labour, was also considered as variable cost and was calculated at the rate of 7 per cent per annum as per the rate charged by the banks. The interest was calculated for half the length of crop production period (i.e., for 3 months).

\section{Rental value of owned land}

It was calculated on the basis of prevailing rates in the sample villages which was one fifth of the gross product.

\section{Land revenue}

Land revenue actually paid to revenue department was considered.

\section{Depreciation}

It is a decline in the value of a given asset as a result of use, wear and tear, accidental damage and time obsolescence. Depreciation was computed on items of fixed capital like farm buildings, irrigation structure and machinery such as thresher and other items excluding tractor because tractor and its accessories were evaluated as hired items. Depreciation was computed on minor agricultural implements used in crop production. Depreciation on an asset was calculated using the straight line method:

Depreciation $=\frac{\text { Purchase price of an asset }- \text { Junk value }}{\text { Expected life of the asset in year }}$

\section{Cost of production (per quintal)}

Cost of production find out by using following formula:

Cost of production per quintal $=\frac{\text { Total } \operatorname{Cost}\left(\operatorname{Cost} \mathrm{C}_{2}\right) / \mathrm{ha}}{\text { Yield } / \mathrm{ha}}$

\section{Operational cost (O.C.)}

It is the variable cost that varies with the level of production. It was expressed as:

$\mathrm{OC}=$ Cost $\mathrm{A}_{1}$ - Land revenue - Depreciation + Family labour charges

\section{Overhead cost (O.H.C.)}

Overhead costs or fixed costs were the sunk costs which had no bearing on the size of production. These were calculated by subtracting variable costs from the cost $\mathrm{C}_{2}$. In other words,

$\mathrm{OHC}=$ Cost $\mathrm{C}_{2}-$ Variable costs

\section{Income measures}

For working out profitability of mungbean cultivation in the study area following income measures was worked out: 
AESSRA

Mahendra et al.

\section{Gross income}

Synonymous with value of output (both main product and by-product) evaluated at harvest prices. Symbolically:

$G I=Q_{m} \times P_{m}+Q_{b} \times P_{b}$

Where,

$$
\begin{aligned}
& G I=\text { Gross Income } \\
& Q_{m}=\text { Quantity of main product } \\
& P_{m}=\text { Price of main product } \\
& Q_{b}=\text { Quantity of by-product } \\
& P_{b}=\text { Price of by-product }
\end{aligned}
$$

\section{Returns over variable cost}

It is the net return over variable cost which was worked out by deducting all items of variable cost from gross income.

Return over variable cost $=$ Gross income - Total variable cost

Family labour income (FLI): It is the return to family labour.

$$
\text { F.L.I. }=\text { Gross income }- \text { Cost } B_{2}
$$

\section{Net income (NI)}

It is the net profit after deducting total cost i.e. variable and fixed costs from gross income.

$\mathrm{NI}=$ Gross income - Total cost $\left(\right.$ Cost $\left.\mathrm{C}_{2}\right)$

Farm business income (FBI): It is the disposal income out of the enterprise and is defined as:

$\mathrm{FBI}=$ Gross income - Cost $\mathrm{A}_{1}$ ( cost $\mathrm{A}_{2}$ in case of tenant operated land)

\section{Return per rupee (RPR)}

$\mathrm{RPR}=\frac{\text { Gross Income } / \text { ha }}{\text { Total Cost }\left(\text { Cost } \mathrm{C}_{3}\right) / \mathrm{ha}}$

\section{RESULTS AND DISCUSSION}

\section{Utilization of farm inputs in physical quantity in mungbean}

Various physical inputs used in the cultivation of mungbean of sample farms of different size holdings are presented in table 1 . That indicates the utilization of machine labour varied from $6.49 \mathrm{hrs} /$ ha on marginal farms to $10.40 \mathrm{hrs} / \mathrm{ha}$ on large farms.
Overall machine labour utilization was $8.63 \mathrm{hrs} / \mathrm{ha}$ which was more than that utilized on marginal, small and semi-medium farms. The more utilization of machine labour on large farms was due to intensive use of tractor intercultural operation.

Utilization of family labour was inversely related to hired human labour. It (family labour) decreased with increase in the size of farms and the hired human labour increased with the increase in the size of farms. Utilization of total human labour was highest (33.04 man days/ha) on marginal farms and lowest (24.68 man days/ha) on large farms. Overall utilization of human labour was estimated at 28.63 man days/ha which was more than that utilized on semi-medium, medium and large farms (Singh et al. 2006).

\section{Utilization of farm inputs in monetary terms in mungbean}

The utilization of farm inputs in monetary terms in mungbean is presented in table 2. The major component of cost was human labour which accounted for ₹ 7358.52 (25.36 per cent) of the total cost of cultivation. The family labour charges accounted for ₹ 6748.87 the higher on marginal farms to ₹ 1814.9 the lower on large farms with an overall charge of ₹ 4481.56 per hectare. The hired labour charge was estimated to be ₹ 4232.7 the higher on large farms and lowest ₹ 1687.22 on marginal farms with overall charges being ₹ 2877.16 per hectare. Interest on working capital and fixed capital jointly accounted for 1.12 per cent of the total cost. These results were in conformation with that reported by Hedge et al. (2013).

\section{Cost of Cultivation}

The Table 3 reveals that the cost $C_{2}$ was $₹$ 29175.27, ₹ 29022.29, ₹ 28994.51, ₹ 28985.32 and ₹ 28886.34 on marginal, small, semi-medium, medium and large farms with an overall cost of ₹ 29012.8. Cost $\mathrm{C}_{3^{\prime}}$ which includes managerial cost $\left(10 \%\right.$ of $\mathrm{C}_{2}$ cost), was worked out to be ₹ 31914.06 per hectare. These results were in conformation with that reported by Tiwari and More (2012) and Singh et al., (2020).

\section{Net profit from the cultivation of mungbean farms (2015-16)}

Net profit from the cultivation of mungbean is 
Table 1: Utilization of farm inputs in physical quantity in mungbean (2015-16)

\begin{tabular}{|c|c|c|c|c|c|c|c|}
\hline S1. No. & $\begin{array}{ll}\text { Inputs } & \text { Farms size } \\
\end{array}$ & Marginal & Small & Semi- Medium & Medium & Large & Overall \\
\hline \multirow[t]{4}{*}{1} & Machine labour in hrs/ha & & & & & & \\
\hline & A. Tractor & 6.49 & 6.66 & 6.40 & 8.61 & 10.40 & 7.71 \\
\hline & B. Thresher & 0.83 & 0.85 & 0.75 & 0.90 & 1.28 & 0.92 \\
\hline & Total machine labour (hrs/ha) & 7.32 & 7.51 & 7.15 & 9.51 & 11.68 & 8.63 \\
\hline \multirow[t]{4}{*}{2} & Human Labour in man days/ha & & & & & & \\
\hline & A. Family Labour & 26.43 & 21.59 & 20.42 & 11.96 & 7.41 & 17.56 \\
\hline & B. Hired labour & 6.61 & 9.25 & 8.75 & 13.46 & 17.28 & 11.07 \\
\hline & Total human labour & 33.04 & 30.84 & 29.18 & 25.42 & 24.68 & 28.63 \\
\hline 3 & Seed $(\mathrm{Kg} / \mathrm{ha})$ & 13.61 & 13.87 & 14.12 & 14.31 & 14.51 & 14.08 \\
\hline \multirow[t]{4}{*}{4} & Fertilizer in $\mathrm{Kg} / \mathrm{ha}$ & & & & & & \\
\hline & A. Nitrogen & 5.12 & 6.64 & 6.78 & 8.60 & 12.77 & 7.98 \\
\hline & B. Phosphorus & 13.18 & 17.07 & 17.45 & 22.11 & 32.82 & 20.53 \\
\hline & C. Total & 18.3 & 23.7 & 24.13 & 30.71 & 45.59 & 28.51 \\
\hline 5 & Plant Protection (Lit/ha) & 0.42 & 0.47 & 0.50 & 0.62 & 0.83 & 0.57 \\
\hline 6 & Manures (Cart loads/ha) & 2.19 & 1.80 & 1.66 & 1.25 & 1.18 & 1.62 \\
\hline
\end{tabular}

Table 2: Utilization of farm inputs in monetary terms in mungbean crop (₹/ha)

\begin{tabular}{|c|c|c|c|c|c|c|c|}
\hline $\begin{array}{l}\text { Sl. } \\
\text { No. }\end{array}$ & Farm inputs & Marginal & Small & Semi-medium & Medium & Large & Overall \\
\hline$\overline{1}$ & Rental value of land & $9299.6(31.87)$ & $9597.4(33.06)$ & $10037.6(34.61)$ & $10734(37.03)$ & $11232.8(38.88)$ & $10180.28(35.08)$ \\
\hline \multirow[t]{4}{*}{2} & Machine labour & & & & & & \\
\hline & A. Owned & $270.35(0.92)$ & $598.81(2.06)$ & $1445.33(4.98)$ & $2860.83(9.86)$ & $3630.6(12.56)$ & $1761.18(6.07)$ \\
\hline & B. Hired & $3269.09(11.20)$ & 3151.34 (10.86) & $2803.92(9.67)$ & $1361.04(4.69)$ & $1006.9(3.48)$ & 2318.458 (7.99) \\
\hline & C. Total & $3539.44(12.13)$ & 3750.15 (12.92) & 4249.25 (14.65) & $4221.87(14.56)$ & $4637.5(16.05)$ & $4079.642(14.06)$ \\
\hline \multirow[t]{4}{*}{3} & Human labour & & & & & & \\
\hline & A. Family labour & $6748.86(23.13)$ & ) 6191.89 (21.33) & $4613.86(15.91)$ & 3038.09 (10.48) & $1814.9(6.28)$ & $4481.36(15.44)$ \\
\hline & B. Hired labour & $1687.22(5.78)$ & $2012.29(6.93)$ & $2739.47(9.44)$ & $3713.99(12.81)$ & $4232.7(14.65)$ & $2877.16(9.91)$ \\
\hline & C. Total & $8436.12(28.91)$ & $8204.18(28.26)$ & $7353.33(25.36)$ & $6752.08(23.29)$ & $6046.6(20.93)$ & $7358.52(25.36)$ \\
\hline 4 & Seed & $1153.46(3.95)$ & $1217.09(4.19)$ & $1245.28(4.29)$ & $1270.22(4.38)$ & $1299.3(4.49)$ & $1237.15(4.26)$ \\
\hline 5 & Total Fertilizer & $415.73(1.42)$ & $562.43(1.93)$ & $603.32(2.08)$ & $789.4(2.72)$ & $802.1(2.77)$ & $634.6(2.18)$ \\
\hline 6 & Total Plant protection & $216.89(0.74)$ & $240.79(0.82)$ & $269.79(0.93)$ & $301.7(1.04)$ & $342.91(1.18)$ & $274.41(0.94)$ \\
\hline 7 & Manure (FYM) & 4613.09 (15.81) & 3385.41 (11.66) & $2960.03(10.20)$ & $2500.22(8.62)$ & $1968.7(6.811)$ & 3085.39 (10.63) \\
\hline 8 & Depreciation & $1129.73(3.87)$ & $1690.48(5.82)$ & $1929.02(6.65)$ & $2112.58(7.28)$ & $2268.96(7.85)$ & $1826.15(6.29)$ \\
\hline 9 & Interest on working capital & $132.95(0.45)$ & $138.92(0.47)$ & $142.39(0.49)$ & $144.48(0.49)$ & $162.17(0.56)$ & $144.18(0.49)$ \\
\hline \multirow[t]{2}{*}{10} & Interest on fixed capital & $238.3(0.81)$ & $235.44(0.81)$ & $204.5(0.70)$ & $158.77(0.54)$ & $125.3(0.43)$ & $192.46(0.66)$ \\
\hline & Total & $29175.27(100)$ & $29022.29(100)$ & $28994.51(100)$ & $28985.32(100)$ & $28886.34(100)$ & $29012.78(100)$ \\
\hline
\end{tabular}

Table 3: Cost of cultivation of mungbean on different size holdings (2015-16) in (₹/ha)

\begin{tabular}{lllllll}
\hline Cost & Marginal & Small & Semi-medium & Medium & Large & Overall \\
\hline $\operatorname{Cost} \mathrm{A}_{1}$ & 12888.51 & 12997.56 & 14138.55 & 15054.46 & 15714.34 & 14158.68 \\
$\operatorname{Cost} \mathrm{A}_{2}$ & 12888.51 & 12997.56 & 14707.31 & 15423.03 & 16709.82 & 14545.25 \\
$\operatorname{Cost} \mathrm{B}_{1}$ & 13126.81 & 13233 & 14343.05 & 15213.23 & 15839.64 & 14351.14 \\
$\operatorname{Cost} \mathrm{B}_{2}$ & 22426.41 & 22830.4 & 24380.65 & 25947.23 & 27072.44 & 24531.42 \\
$\operatorname{Cost} \mathrm{C}_{1}$ & 19875.67 & 19424.89 & 18956.91 & 18251.32 & 17654.54 & 18832.5 \\
$\operatorname{Cost} \mathrm{C}_{2}$ & 29175.27 & 29022.29 & 28994.51 & 28985.32 & 28886.34 & 29012.8 \\
$\operatorname{Cost} \mathrm{C}_{3}$ & 32092.8 & 31924.52 & 31893.96 & 31883.85 & 31776.07 & 31914.06 \\
\hline
\end{tabular}


presented in table 4indicates that overall gross return, total cost and net profit on mungbean were worked out at ₹ 50901, ₹ 29013 and ₹ 21889 per hectare, respectively. Gross return was highest (₹ 56164) on large farms and lowest (₹ 46498) on marginal farms. Similarly, total costs varied from ₹ 29886 on large farms to ₹ 29175 on marginal farms. Net profit was ₹ 27278 on large farms. It was ₹ 24685 , ₹ 21193 , ₹ 18965 and ₹ 17323 on medium, semi-medium, small and marginal farms with an overall net profit of ₹ 21889 (Kumar et al. 2019).

The gross return was more on large farms because of timely weeding, hoeing, improve seed, harvesting and more availability of capital and machinery on scale of production. The total costs incurred on cultivation of mungbean were higher on marginal farms due to higher use of human labour and farm yard manure. Total costs on cultivation of mungbean were lower on large farms due to high machine labour used, low use of human labour and farm yard manure in Nagaur district of Rajasthan.

Table 4: Net profit from the cultivation of mungbean (2015-16) in (₹/ha)

\begin{tabular}{lllll}
\hline $\begin{array}{l}\text { Sl. } \\
\text { No. }\end{array}$ & Farm size & $\begin{array}{l}\text { Gross } \\
\text { return }\end{array}$ & $\begin{array}{l}\text { Total } \\
\text { cost }\end{array}$ & $\begin{array}{l}\text { Net } \\
\text { profit }\end{array}$ \\
\hline 1 & Marginal farms & 46498 & 29175 & 17323 \\
2 & Small farms & 47987 & 29022 & 18965 \\
3 & Semi-medium farms & 50188 & 28995 & 21193 \\
4 & Medium farms & 53670 & 28985 & 24685 \\
5 & Large farms & 56164 & 28886 & 27278 \\
\hline & Overall & $\mathbf{5 0 9 0 1}$ & $\mathbf{2 9 0 1 3}$ & $\mathbf{2 1 8 8 9}$ \\
\hline
\end{tabular}

Family labour income, family business income and returns per rupee from the cultivation of mungbean

The table 5 indicates that the overall family labour income, family business income and returns per rupee were estimated at ₹ 26370, ₹ 36526 and ₹ 1.60 per hectare, respectively.

Table 5: Family labour income, Family business income and returns per rupee from the cultivation of mungbean (2015-16) (₹/ha)

\begin{tabular}{lllll}
\hline $\begin{array}{l}\text { S1. } \\
\text { No. }\end{array}$ & Farm size & $\begin{array}{l}\text { Family } \\
\text { labour } \\
\text { income }\end{array}$ & $\begin{array}{l}\text { Family } \\
\text { business } \\
\text { income }\end{array}$ & $\begin{array}{l}\text { Returns per } \\
\text { rupee }\end{array}$ \\
\hline 1 & $\begin{array}{l}\text { Marginal } \\
\text { farms }\end{array}$ & 24072 & 33609 & 1.45 \\
2 & Small farms & 25157 & 34989 & 1.50
\end{tabular}

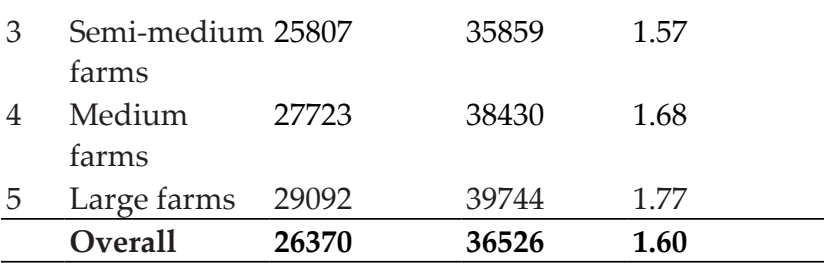

The family labour income varied from as low as ₹ 24072 on marginal farms to as high as ₹ 29092 on large farms. Similarly, Family business income was highest (₹ 39744) on large farms and lowest (₹ 33609) on marginal farms.

Returns per rupee were worked out to be ₹ 1.45 , $₹ 1.50$, ₹ 1.57 , ₹ 1.68 and ₹ 1.77 on marginal, small, semi-medium, medium and large farms, respectively. These findings were in conformity with Tawale et al. (2011).

\section{Operational costs, overhead costs and costs of production from the cultivation of mungbean on different farms}

The table 6 reveals that the overall operational costs, overhead costs and costs of production on ₹ 16814, $₹ 12199$ and ₹ 4534 per hectare. Category wise costs of production ranged from ₹ 4993 on marginal farms followed by ₹ 4723, ₹ 4561, ₹ 4277 and ₹ 4115 on small, semi-medium, medium and large farms.

Table 6: Operational costs, overhead costs and costs of production from the cultivation of mungbean (2015-16)

\begin{tabular}{lllll}
\hline $\begin{array}{l}\text { Sl. } \\
\text { No. }\end{array}$ & Farm size & $\begin{array}{l}\text { Operational } \\
\text { costs (₹/ha) }\end{array}$ & $\begin{array}{l}\text { Overhead } \\
\text { costs (₹/ } \\
\text { ha) }\end{array}$ & $\begin{array}{l}\text { Costs of } \\
\text { production } \\
\text { (₹/q) }\end{array}$ \\
\hline 1 & Marginal farms & 18508 & 10668 & 4993 \\
2 & Small farms & 17499 & 11523 & 4723 \\
3 & $\begin{array}{l}\text { Semi-medium } \\
\text { farms }\end{array}$ & 16823 & 12171 & 4561 \\
4 & Medium farms & 15980 & 13005 & 4277 \\
5 & Large farms & 15260 & 14591 & 4115 \\
\hline & Overall & $\mathbf{1 6 8 1 4}$ & $\mathbf{1 2 3 9 2}$ & 4534 \\
\hline
\end{tabular}

The overall cost of production was ₹ 4534, which was less than that on medium and large farms. These findings were in conformity with Tawale et al. (2011).

\section{CONCLUSIONS}

1. The gross return was more on large farms because of timely weeding, hoeing, improve seed, harvesting and more availability of capital and machinery. 
2. All types of farm incomes viz., gross income, family labour income, farm business income, returns per rupee and net profit were higher on large farms than on the marginal farms.

3. The operational costs and costs of production were higher on marginal farms and overhead cost was higher on large farms.

4. Overall machine labour utilization was more on large farms than marginal, small and semi-medium farms due to intensive use of tractor intercultural operation.

5. The utilization of human labour was highest on marginal farms and lowest on large farms. Utilization of machine labour was highest on large farms and lowest on marginal farms indicating that machine labour replaced human labour with the increase in size of the farm.

\section{Additional Comments}

- The government should make adequate arrangement for timely supply of necessary inputs at reasonable prices to the growers so as to increase per hectare productivity as well as net returns.

- Bank credit and financial assistance should be available to the individual farmers for increasing the production.

- Training of farmers in the areas of production technology, grading, standardization of produce, quality control and modern method of marketing will prove to be a viable move.

- The government should establish adequate storages at village level for the purpose of orderly marketing of mungbean to benefit both consumers and producers.

- This study was helped the farmers in reducing the cost of cultivation by using appropriate techniques and tools and improve the net return of the farmers in the study area.

\section{ACKNOWLEDGMENTS}

Thankful to my institutions, organizations, laboratories, and farmers who help and support me for my research work.

\section{REFERENCES}

Anonymous, 2014-15. http://www.krishi.rajasthan.gov.in.

Anonymous, 2014-15. Rajasthan Economic Review, Commissionerate of Agriculture, Rajasthan, Jaipur, pp. 48-56.

Chatterjee, S., Nath, R., Ray, J., Ray, M., Gunri, S.K. and Bopadhyay, P. 2014. Analysis of pulse production in major states of India. Journal of Food Legumes, 27(2): 140-145.

Hegde, D., Rao, D.V.S., Vasudev, N. and Supriya, K. 2013. An economic analysis of blackgram in Gulbarga district of Karnataka. Journal of Research ANGRAU, 41(1): 70-73.

Khunt, K.A. and Desai, D.B. 1996. Economic feasibility and marketing of perennial vegetables in South Gujarat. Financing Agriculture, 28: 9-14.

Kumar, R., Kumar, N., Dhillon, A., Bishnoi, D.K., Kavita and Malik, A.K. 2019. Economic analysis of guava in Sonepat district of Haryana. Economic Affairs, 64(4): 747-752.

Maurya, O.P., Singh, G.N. and Kushwaha, R.K.S. 2001. An economic analysis of production and marketing of potato in district Varanasi (UP). In: Encyclopaedia of Agricultural Marketing, Vol. 8, Ed : J. Prasad. New Delhi: Mittal Publications, pp. 229-38.

Mogotsi, 2006 http: // www.feedipedia.org/node/235.

Mohanty, S. and Satyasai, K.J. 2015. Feeling the pulse, Indian pulses sector. National Bank For Agriculture and Rural Development rural pulse, 1: 1-4.

Rao, N.S. and Tripathi, B.N. 1979. A study of economics of production and marketing of some vegetable crops in Kankipadu block of Krishna District, AP. Allahabad Farmer, 50: 341.

Sharma, V.K., Inder Sain and Singh, G. 2000. Income and employment from summer vegetables vis-à-vis paddy in Punjab. Journal of Agriculture Development E Policy, 12: 38-43.

Singh, R., Chahal, S.S. and Kataria, P. 2006. Economics of Production of green peas in Punjab. Agriculture Economics Research Review, 19(2): 237-250.

Singh, N., Sharma, R. and Kayastha, R. 2020. Economic analysis of pea in Himachal Pradesh. Economic Affairs, 65(2): 191-195.

Tawale, J.B., and Pawar, B.R. 2011. Costs, returns and profitability of soybean production in Maharashtra. International Research Journal of Agricultural Economics and Statistics, 2(2): 174-176.

Tiwari, J. and More, S. 2012. Costs, returns and resource use efficiency of soybean cultivation in Indore district of Madhya Pradesh. Agriculture Update, 7(3/4): 214-217. 
